\title{
UPAYA MENINGKATKAN MUTU KETERAMPILAN DASAR MENGAJAR MELALUI SIMULASI PEER TEACHING BERBASIS TEKNIK NYAYA DARSANA
}

\author{
Oleh \\ Ni Kadek Juliantari \\ STKIP Agama Hindu Amlapura \\ kadekjuliantari755@yahoo.co.id
}

Diterima 24 Juli 2018, direvisi 30 Juli 2018, diterbitkan 31 Agustus 2018

\begin{abstract}
This study aims to improve the basic skills of teaching sixth semester students of the Hindu Education Study Program STKIP Agama Hindu Amlapura 2016/2017 academic year through the application of peer teaching simulation based on Nyaya Darsana technique. The subjects in this study were the sixth semester students of the Hindu Education Study Program 2016/2017 academic year totaling 31 people. The data in this study were collected by tests and the results were analyzed quantitatively supported by qualitative interpretations. The results show that the application of peer teaching simulation with Nyaya Darsana technique can improve the basic teaching skills of the sixth semester students of the Hindu Education Study Program STKIP Agama Hindu Amlapura 2016/2017 academic year from the percentage of success in the first cycle of $87,10 \%$ to $93,55 \%$ in cycle II. Meanwhile, the average value also increased from 73.42 in the first cycle to 74,97 in the second cycle. Therefore, the application of peer teaching simulation with Nyaya Darsana technique is recommended to be used in lectures that target the formation of skills or competencies of prospective teachers.
\end{abstract}

\section{Keywords: Basic Teaching Skills, Peer Teaching, Nyaya Darsana}

\section{PENDAHULUAN}

Upaya memperbaiki dan meningkatkan mutu pendidikan seakan tidak pernah berhenti diperbincangkan oleh berbagai kalangan, terutama kalangan yang bergelut dalam bidang pendidikan. Upaya-upaya yang dilakukan dalam memperbaiki dan meningkatkan mutu pendidikan sangat beragam, mulai dari pembaharuan kurikulum hingga peningkatan profesionalisme guru yang gencar dilakukan melalui programprogram yang dipandang strategis, seperti program sertifikasi guru. Hal tersebut jelas menunjukkan bahwa upaya memperbaiki dan meningkatkan mutu pendidikan tidak bisa hanya dilakukan orang perseorangan, tetapi harus bersinergi dan setiap komponen yang 
terlibat di dalamnya haruslah dipotimalkan sedemikian rupa.

Sebagai contohnya, upaya peningkatan mutu pendidikan tidak cukup hanya dalam bidang pembaharuan kurikulum, tanpa diikuti dengan penyiapan tenaga pendidik yang profesional dan berkompeten di bidangnya. Pembaharuan kurikulum akan lebih bermakna bila diikuti dengan perubahan praktik pembelajaran di dalam ataupun di luar kelas. Indikator pembaharuan kurikulum ditunjukkan dengan adanya perubahan pola kegiatan pembelajaran, pemilihan media pendidikan, penentuan pola penilaian yang menentukan hasil pendidikan. Keberhasilan implementasi kurikulum sangat dipengaruhi oleh kemampuan guru yang akan menerapkan dan mengaktualisasikan kurikulum tersebut. Kemampuan guru tersebut terutama berkaitan dengan pengetahuan dan kemampuan, serta tugas yang dibebankan kepadanya. Kegagalan pengimplementasian kurikulum disebabkan oleh kurangnya pengetahuan, keterampilan, dan kemampuan guru dalam memahami tugas-tugas yang harus dilaksanakannya. Oleh karena itu, tidak dapat dipungkiri bahwa faktor guru menjadi salah satu penentu keberhasilan implementasi kurikulum yang mengarah pada keberhasilan peningkatan mutu pendidikan atau pembelajaran di sekolah.

Guru dalam menjalankan profesinya diharapkan memiliki kompetensi. Kompetensi guru tersebut menurut Majid (2011:5) merupakan seperangkat tindakan intelegen penuh tanggung jawab yang harus dimiliki oleh seorang guru sebagai syarat untuk dianggap mampu melaksanakan tugastugas dalam bidang pekerjaannya tersebut. Kompetensi yang wajib dimiliki oleh seorang guru adalah kompetensi pedagogik, kompetensi profesional, kompetensi personal, dan kompetensi sosial.

Kompetensi pedagogik merupakan kemampuan mengelola pembelajaran peserta didik yang meliputi pemahaman terhadap peserta didik, perancangan dan pelaksanaan pembelajaran, evaluasi hasil belajar dan pengembangan peserta didik untuk mengaktualisasikan berbagai potensi yang dimilikinya (SNP, penjelasan Pasal 28 ayat 3 butir a). Kompetensi profesional adalah kemampuan penguasaan materi pembelajaran secara luas dan mendalam yang memungkinkan membimbing peserta didik memenuhi standar kompetensi yang ditetapkan dalam Standar Nasional Pendidikan (SNP, penjelasan Pasal 28 ayat 3 butir c). Kompetensi personal adalah kemampuan kepribadian yang mantap stabil, dewasa, arif, dan berwibawa, mendaji teladan bagi peserta didik, dan berakhlak mulia (SNP, penjelasan pasal 28 ayat 3 butir b). Kompetensi sosial adalah kemampuan guru sebagai bagian dari masyarakat untuk berkomunikasi dan bergaul secara efektif dengan peserta didik, sesama pendidik, tenaga kependidikan, orang tua/wali peserta didik, dan masyarakat sekitar (SNP, penjelasan pasal 28 ayat 3 butir $\mathrm{d}$ ).

Berdasarkan uraian kompetensi guru tersebut dapat diketahui bahwa profesi guru mengemban tugas yang kompleks. Dengan demikian, lembaga pendidikan tinggi yang bergerak dalam mencetak tenaga kependidikan perlu mengimplementasikan berbagai strategi dalam rangka menyiapkan calon-calon guru tersebut agar siap bersaing dan mengemban misi pendidikan, terutama upaya-upaya yang secara langsung menyentuh pada profesinya kelak. Upaya tersebut dapat diaplikasikan melalui pengelolaan mata kuliah. Salah satunya adalah Mata Kuliah Teori dan Praktik Keguruan yang ditekankan pada pembentukan keterampilan dasar mengajar bagi mahasiswa calon guru.

Keterampilan dasar mengajar (teaching skills) merupakan suatu karakteristik umum dari seseorang yang berhubungan dengan pengetahuan dan keterampilan yang diwujudkan melalui tindakan. Keterampilan dasar mengajar ini penting dimiliki oleh setiap mahasiswa calon guru, karena kelak profesi guru yang akan digelutinya menuntut keterampilan mereka dalam mengajar dan membelajarkan para siswanya. Jika mereka tidak siap dengan tuntutan tersebut, tentu mereka akan tersingkir dari persaingan dunia kerja.

Hasil observasi saat perkuliahan Pengelolaan Kelas menunjukkan bahwa 
mahasiswa semester $\mathrm{V}$ yang diamati masih malu-malu tampil di depan kelas. Perkuliahan Pengelolaan Kelas digunakan sebagai dasar refleksi awal karena pada dasarnya mata kuliah Pengelolaan Kelas yang muncul pada semester $\mathrm{V}$ tersebut menjadi prasyarat mata kuliah Teori dan Praktik Keguruan, yang penekanannya adalah praktik keterampilan dasar mengajar, yang muncul pada semester VI.

Selain masih malu tampil di depan kelas, mahasiswa juga kurang antusias dalam kegiatan perkuliahan yang dilaksanakan. Padahal pengelolaan kelas yang telah dilakukan diupayakan sedemikian rupa agar mahasiswa memperoleh model-model pengelolaan kelas yang dapat digunakannya sebagai bekal dalam mata kuliah selanjutnya, yakni Mata Kuliah Teori dan Praktik Keguruan. Di samping itu, keberagaman karakteristik mahasiswa dalam kelas tersebut juga menjadi faktor penentu keberhasilan kegiatan pembelajaran/perkuliahan yang diselenggarakan.

Berdasarkan permasalahan yang dihadapi tersebut, hal-hal yang perlu diperhatikan dalam perkuliahan selanjutnya, yakni pada semester VI, terutama pada Mata Kuliah Teori dan Praktik Keguruan adalah menanamkan kepercayaan diri kepada mahasiswa agar dapat secara optimal mengembangkan potensi dirinya yang berkaitan dengan keterampilan dasar mengajar.

Salah satu upaya yang dilakukan untuk mengoptimalkan penggalian potensi mahasiswa terkait dengan keterampilan dasar mengajar adalah melalui simulasi peer teaching berbasis teknik nyaya darsana. Simulasi dapat diartikan sebagai cara penyajian pengalaman belajar dengan menggunakan situasi tiruan untuk memahami tentang konsep, prinsip, atau keterampilan tertentu. Simulasi dapat digunakan sebagai metode mengajar dengan asumsi tidak semua proses pembelajaran dapat dilakukan secara langsung pada objek yang sebenarnya. Misalnya, dalam perkuliahan Teori dan Praktik Keguruan, tidak memungkinkan situasi senyatanya dibawa ke kelas, yakni menghadirkan siswa sungguhan dalam proses perkuliahan. Oleh karena itu, perlu diadakan simulasi peer teaching, yakni dengan cara mahasiswa yang berlatih keterampilan dasar mengajar berperan sebagai guru, sedangkan mahasiswa lainnya berperan sebagai siswa, dan bertindak selayaknya siswa. Setiap mahasiswa secara bergiliran melakukan simulasi seperti itu. Simulai yang demikian dinamakan simulasi peer teaching, karena mahasiswa berpura-pura sebagai seorang guru yang sedang menghadapi situasi kelas dan siswa senyatanya.

Pelaksanaan simulasi peer teaching ini dipandang lebih optimal apabila didukung dengan teknik nyaya darsana. Teknik nyaya darsana ini menekankan pemerolehan pengetahuan melalui 4 (empat) cara, yakni pratyaksa (pengamatan), anumana (penyimpulan), upamana (perbandingan), dan sabda (pemberian kesaksian). Perpaduan simulasi peer teaching ini dengan teknik nyaya darsana dipandang optimal karena keterampilan dasar mengajar yang diharapkan dapat diperoleh mahasiswa melalui mengamati (pratyaksa) teman yang sebelumnya tampil, menyimpulkan (anumana) cara mengelola kegiatan pembelajaran melalui membandingkan (upamana) mahasiswa yang tampil sebelumnya, dan mahasiswa memperoleh penjelasan/kesaksian (sabda) dari orangorang yang terampil mengelola pembelajaran. Dengan cara seperti itu, diharapkan keterampilan dasar mengajar mahasiswa semester VI Program Studi Pendidikan Agama Hindu dapat dioptimalkan.

Berdasarkan uraian latar belakang tersebut, timbul ketertarikan untuk menyusun penelitian dengan judul Upaya Meningkatkan Keterampilan Dasar Mengajar melalui Simulasi Peer Teaching Berbasis Teknik Nyaya Darsana pada Mahasiswa Semester VI Program Studi Pendidikan Agama Hindu STKIP Agama Hindu Amlapura Tahun Akademik 2016/2017.

Berdasarkan uraian latar belakang tersebut, permasalahan yang dirumuskan dalam penelitian ini adalah sebagai berikut. Bagaimanakah peningkatan keterampilan dasar mengajar mahasiswa semester VI Program Studi Pendidikan Agama Hindu 
STKIP Agama Hindu Amlapura tahun akademik 2016/2017 setelah diterapkan simulasi peer teaching berbasis teknik nyaya darsana?

Sejalan dengan rumusan masalah tersebut, tujuan yang ingin dicapai dalam penelitian ini sebagai berikut: untuk meningkatkan keterampilan dasar mengajar mahasiswa semester VI Program Studi Pendidikan Agama Hindu STKIP Agama Hindu Amlapura tahun akademik 2016/2017 melalui penerapan simulasi peer teaching berbasis teknik nyaya darsana.

Manfaat dalam penelitian ini ada 2 (dua), yakni manfaat teoretis dan manfaat praktis. Secara teoretis, hasil penelitian ini diharapkan dapat menambah referensi terkait dengan upaya peningkatan keterampilan dasar mengajar. Di samping itu, hasil penelitian ini diharapkan juga dapat memperkaya khasanah teori yang terkait dengan simulasi peer teaching dan teknik nyaya darsana dalam peningkatan keterampilan dasar mengajar.

Secara praktis, hasil penelitian ini diharapkan bermanfaat bagi pihak-pihak berikut. Bagi Mahasiswa/Calon Guru, hasil penelitian ini diharapkan dapat memberikan pengalaman langsung kepada mahasiswa calon guru dalam mengelola kegiatan pembelajaran, sehingga keterampilan dasar mengajar yang dimilikinya semakin terasah dan optimal. Bagi Dosen, hasil penelitian ini diharapkan dapat diaplikasikan dalam perkuliahan serupa, terutama pada Mata Kuliah yang menekankan pada keterampilan agar kegiatan perkuliahan dapat berlangsung secara optimal dan potensi mahasiswa dapat digali secara maksimal. Bagi Lembaga STKIP Agama Hindu Amlapura, hasil penelitian ini diharapkan dapat dijadikan dasar pengambilan kebijakan terutama yang berkaitan dengan perealisasian visi dan misi lembaga sebagai salah satu Lembaga Pendidikan Tenaga Kependidikan (LPTK) Hindu di Karangasem.

\section{METODE}

Ada dua jenis data yang dikumpulkan dalam penelitian ini, yakni (1) peningkatan keterampilan dasar mengajar setelah diterapkan simulasi peer teaching berbasis teknik nyaya darsana dan (2) kendalakendala yang dihadapi oleh mahasiswa saat melakukan simulasi peer teaching berbasis teknik nyaya darsana. Berdasarkan data tersebut, dapatlah diketahui cara yang tepat digunakan untuk mengumpulkan data tersebut. Metode pengumpulan data yang digunakan adalah tes.

Tes yang tepat digunakan untuk mengukur keterampilan dasar mengajar yang dimiliki oleh mahasiswa adalah tes unjuk kerja/unjuk laku atau sering disebut dengan tes praktik atau tes performance. Dalam penelitian ini, tes praktik/tes unjuk laku digunakan untuk mengumpulkan data terkait dengan masalah yang pertama, yakni peningkatan keterampilan dasar mengajar mahasiswa semester VI Program Studi Pendidikan Agama Hindu. Melalui tes unjuk laku tersebut, dapat diketahui keterampilan dasar mengajar mahasiswa semseter VI yang diteliti.

Analisis data yang digunakan dalam penelitian ini adalah perpaduan antara analisis data deskriptif kuantitatif dan deskriptif kualitatif. Deskriptif kuantitatif digunakan untuk menganalisis data peningkatan keterampilan dasar mengajar, yang selanjutnya diinterpretasikan secara deskriptif kualitatif.

Nilai rata-rata klasikal diperoleh melalui rumus berikut.

$$
M=\frac{\sum x}{n}
$$

Keterangan :

$$
\begin{array}{ll}
\mathrm{M} & =\text { nilai rata-rata kelas } \\
\sum X & =\text { Jumlah nilai siswa keseluruhan } \\
\mathrm{n} & =\text { Jumlah siswa }
\end{array}
$$

(Sudijono, $2006: 81$ )

Selain analisis secara kuantitatif dengan menggunakan rumus di atas, hasilnya juga dipaparkan secara naratif verbal yang digunakan dasar untuk menyimpulkan..

Penelitian ini dikatakan berhasil apabila minimal $75 \%$ mahasiswa memperoleh nilai pada kategori baik dengan indeks 3,0 sesuai tabel berikut. 


\begin{tabular}{|l|l|l|}
\hline Nilai & Huruf & Indeks \\
\hline $80,00-100,00$ & A & 4,00 \\
\hline $70,00-79,00$ & B & 3,00 \\
\hline $60,00-69,00$ & C & 2,00 \\
\hline $50,00-59,00$ & D & 1,00 \\
\hline $40,00-49,00$ & E & 1,00 \\
\hline
\end{tabular}

\section{HASIL DAN PEMBAHASAN}

Hasil evaluasi terhadap keterampilan dasar mengajar mahasiswa setelah diterapkan simulasi peer teaching dengan teknik Nyaya Darsana sebagai berikut.

\begin{tabular}{|c|c|c|c|}
\hline \multirow[t]{2}{*}{ No } & \multirow[t]{2}{*}{ Interval Nilai (Kategori) } & \multicolumn{2}{|c|}{ Frekuensi } \\
\hline & & Siklus I & Siklus II \\
\hline 1 & $80-100(\mathrm{~A})$ & 3 & 3 \\
\hline 2 & $70-79(\mathrm{~B})$ & 24 & 26 \\
\hline 3 & $60-69(\mathrm{C})$ & 4 & 2 \\
\hline 4 & $50-59(\mathrm{D})$ & 0 & 0 \\
\hline 5 & $40-49(\mathrm{E})$ & 0 & 0 \\
\hline & Jumlah & 31 & 31 \\
\hline & Jumlah Nilai & 2275 & 2324 \\
\hline & Rata-rata nilai & 73,42 & 74,97 \\
\hline & Persentase keberhasilan & $87,10 \%$ & $93,55 \%$ \\
\hline
\end{tabular}

Berdasarkan hasil tersebut dapat diketahui bahwa pelaksanaan siklus I sudah berhasil, tetapi tetap dilanjutkan pada siklus II untuk membuktikan bahwa keberhasilan tersebut memang karena penerapan simulasi peer teaching berbasis teknik Nyaya Darsana, bukan karena faktor yang lain. Dari hasil evaluasi tersebit dapat diketahui bahwa terjadi peningkatan keterampilan dasar mengajar pada mahasiswa semester VI tahun akademik 2016/2017 setelah diterapkan simulasi peer teaching berbasis teknik Nyaya Darsana.

Keberhasilan ini terjadi karena beberapa hal sebagai berikut. Pertama, simulasi peer teaching dengan teknik Nyaya Darsana dapat memberikan kesempatan pada mahasiswa untuk mengamati rekan lain yang sedang praktik mengajar. Mahasiswa yang mengamati tersebut mendapat pengalaman baru dari mahasiswa lain yang praktik, kemudian membandingkannya dengan pengetahuan yang telah dimilikinya sebelumnya.

Kedua, simulasi peer teaching dengan teknik Nyaya Darsana dapat membantu mahasiswa untuk mendapatkan pengalaman yang sangat berguna mengenai teknik dan metode pembelajaran dalam kelas. Mahasiswa kemungkinan lemah dalam penggunaan metode ataupun teknik membelajarkan siswa, sehingga dengan mengamati teman lainnya yang praktik, maka mahasiswa tersebut mendapat tambahan pengetahuan terkait penerapan metode ataupun teknik membelajarkan siswa.

Ketiga, simulasi peer teaching dengan teknik Nyaya Darsana dapat memberikan motivasi terhadap aktivitas mengajar. Mahasiswa dapat termotivasi dari aktvitas yang dilakukan oleh mahasiswa lainnya. Melalui kegiatan praktik secara bergilir, setiap mahasiswa mendapat kesempatan menjadi pengamat dan model di depan kelas. Pengalaman langsung seperti ini sangat bermakna bagi pembentukan keterampilan mahasiswa.

Keempat, simulasi peer teaching dengan teknik Nyaya Darsana dapat menciptakan suasana kewajaran dalam berdiskusi mengenai masalah yang dihadapi. Hal ini terjadi karena masalah yang muncul bisa diamati secara bersama-sama sehingga solusi 
atas permasalahan tersebut pun bisa dicari secara bersama-sama melalui diskusi setelah kegiatan perkuliahan dilakukan. Simulasi peer teaching dengan teknik Nyaya Darsana ini dirasakan lebih bermanfaat karena telah direncanakan dengan baik dengan prinsip kooperatif antarmahasiswa.

Atas dasar beberapa faktor tersebutlah, penerapan simulasi peer teaching dengan teknik Nyaya Darsana ini dapat meningkatkan keterampilan dasar mengajar pada mahasiswa semester VI Program Studi Pendidikan Agama Hindu STKIP Agama Hindu Amlapura tahun akademik 2016/2017.

Hasil serupa juga diperoleh Suardeyasa (2010) dalam penelitian yang berjudul Penggunaan Teknik Nyaya Darsana dalam Meningkatkan Pemahaman Siswa terhadap Ajaran Widi Tattwa pada Mata Pelajaran Pendidikan Agama Hindu di Kelas IV SD Negeri 6 Tianyar Barat Tahun Ajaran 2009/2010. Hasil penelitiannya menunjukkan bahwa penggunaan teknik nyaya darsana dalam meningkatkan pemahaman siswa terhadap ajaran Widi Sraddha di Kelas IV SD Negeri 6 Tianyar Barat dilakukan dengan mengembangkan ajaran Nyaya yakni upamana pramana, pratyaksa pramana, dan agama pramana. Sisi pratyaksa pramana tidak dapat diterapkan dalam pembelajaran ini, sehingga teknik upamana dan sabda pramana adalah dua teknik yang secara bersamaan dapat digunakan dalam menjelaskan konsep-konsep Widi Sraddha dalam ajaran Agama Hindu. Teknik nyaya darsana dapat digunakan secara efektif dalam meningkatkan pemahaman siswa di SD Negeri 6 Tianyar Barat, yang dibuktikan melalui perolehan nilai siswa yang meningkat dari rata-rata 7,0 meningkat menajdi 7,8 dan 7,2 . Dengan persentase keberhasilan pada siklus ke 2, pencapaian nilai 7 mencapai $80,48 \%$, perolehan nilai 8 mencapai $12,19 \%$, sedangkan perolehan nilai 9 mencapai 7,31\%.

Berdasarkan hal tersebut, teknik Nyaya Darsana yang merupakan kearifan lokal agama Hindu dapat diterapkan dalam kegiatan pembelajaran apapun demi pencapaian tujuan pembelajaran secara optimal. Dalam filsafat Nyaya, diuraikan mengenai empat alat untuk mendapatkan pengetahuan yang benar, yakni pratyaksa pramana, anumana pramana, upamana pramana, dan sabda pramana.

1) Partyaksa Pramana

Pratyaksa Pramana merupakan ajaran tentang pengamatan langsung. Beranalogi dari cara berpikir ini, dalam penelitian ini yang diamati adalah cara atau kegiatan praktik mengajar yang dilakukan. Melalui pengamatan tersebut, diharapkan akan diperoleh pengetahuan yang benar terkait dengan kegiatan praktik mengajar yang dilakukan oleh guru, terutama yang berkaitan dengan keterampilan dasar mengajar harus dimiliki oleh guru ataupun calon guru.

2) Anumana Pramana

Anumana Pramana mengandung ajaran tentang penyimpulan. Penyimpulan dari hasil pengamatan yang dilakukan.

3) Upamana Pramana

Upamana Pramana adalah alat untuk mendapatkan pengetahuan yang benar berdasarkan perbandingan antara nama dan objek. Teknik upamana ini diterapkan dengan cara membandingkan simulasi praktik mengajar yang satu dengan yang lainnya, sehingga pada akhirnya diperoleh pengetahuan yang benar terhadap kegiatan praktik mengajar.

4) Sabda Pramana

Sabda adalah cara untuk mendapatkan pengetahuan dengan cara kesaksian. Dalam kaitannya dengan penelitian ini, teknik sabda diaplikasikan melalui kesaksian dari orang-orang yang dalam kesehariannya terlibat langsung dalam dunia pembelajaran, misalnya guru Pendidikan Agama Hindu yang sudah terbiasa mengelola kegiatan pembelajaran dan pengawas Pendidikan Agama Hindu yang sudah terbiasa melakukan kegiatan supervisi terhadap guru-guru Pendidikan Agama Hindu binaannya.

Keterampilan dasar mengajar (teaching skills) merupakan suatu karakteristik umum dari seseorang yang berhubungan dengan 
pengetahuan dan keterampilan yang diwujudkan melalui tindakan (Juliantari, 2013:30). Keterampilan dasar mengajar (teaching skills) pada dasarnya merupakan bentuk-bentuk perilaku yang mendasar dan khusus yang harus dimiliki oleh seorang guru sebagai modal awal untuk melaksanakan tugas-tugas pebelajarannya secara terencana dan professional. Keterampilan dasar mengajar guru secara aplikatif indikatornya dapat digambarkan melalui sembilan keterampilan mengajar, yakni keterampilan membuka pelajaran, keterampilan bertanya, keterampilan memberi penguatan, keterampilan mengadakan variasi, keterampilan menjelaskan, keterampilan membimbing kelompok kecil, keterampilan mengelola kelas, keterampilan pembelajaran perseorangan, dan keterampilan menutup pembelajaran.

Kegiatan membuka pelajaran adalah kegiatan yang dilakukan untuk memulai pembelajaran. Membuka pelajaran adalah usaha atau kegiatan yang dilakukan oleh guru dalam kegiatan pembelajaran untuk menciptakan pra-kondisi bagi siswa agar mental ataupun perhatian siswa terpusat pada apa yang akan dipelajarinya. Oleh karena itu, usaha tersebut akan memberikan efek yang positif terhadap kegiatan belajar.

Dalam kegiatan pembelajaran, bertanya memainkan peranan penting karena pertanyaan yang tersusun dengan baik dn teknik melontarkan pertanyaan yang tepat akan memberikan dampak positif terhadap aktivitas dan kreativitas siswa, yakni sebagai berikut: (a) meningkatkan partisipasi siswa dalam kegiatan pembelajaran, (b) membangkitkan minat dan rasa ingin tahu siswa terhadap suatu masalah yang sedang dibicarakan, (c) mengembangkan pola pikir dan cara belajar aktif dari siswa sebab berpikir itu sendiri sesungguhnya adalah bertanya, (d) menuntun proses berpikir siswa sebab pertanyaan yang baik akan membantu siswa agar dapat menentukan jawaban yang baik, dan (e) memusatkan perhatian siswa terhadap masalah yang sedang dibahas.

$$
\text { Secara psikologis, individu }
$$
membutuhkan penghargaan atas segala usaha yang telah dilakukannya, apalagi pekerjaan itu dinilai baik, sukses, dan efektif. Guru yang baik harus selalu memberikan penguatan, baik dalam bentuk penguatan verbal (diungkapkan dengan kata-kata langsung, seperti seratus, excellent, bagus, pintar, ya, betul, tepat, dan sejenisnya) maupun nonverbal (biasanya dilakukan dengan gerak isyarat, sentuha/elusan, pendekatan, dan sejenisnya) yang merupakan bagian dari modifikasi tingkah laku guru terhadap tingkah laku siswa yang bertujuan untuk memberikan informasi atau umpan balik (feeback) bagi siswa atas perbuatan yang baik sebagai suatu tindakan dorongan sehingga perbuatan tersebut terus diulang.

Peserta didik merupakan individu yang unik, heterogen, dan memiliki interes yang berbeda-beda. Siswa ada yang memiliki kecenderungan auditif, yaitu senang mendengarkan, visual yaitu senang melihat, dan kecenderungan kinestetik, yaitu senang melakukan. Oleh karena itulah, huru harus memiliki kemampuan mengadakan variasi dalam kegiatan pembelajaran. Penggunaan multisumber, multimedia, multimetode, multitrategi, dan multimodel. Biarlah pembelajaran dilakukan secara klasikal, tetapi sentuhan harus individual. Artinya, guru perlu menggunakan ceramah untuk siswa yang auditif, guru perlu menggunakan media dan alat peraga untuk siswa yang visual, dan guru harus mengadakan diskusi, eksperimen, demonstrasi, dan praktik untuk siswa yang kinestetik. Bila guru telah melakukan hal tersebut berarti guru telah menyentuh masingmasing interes siswa, sehingga hasil yang diperoleh akan mendekati penilaian yang sebenarnya.

Keterampilan menjelaskan dalam pembelajaran merupakan penyajian informasi secara lisan yang diorganisasi secara sistematis untuk menunjukkan adanya hubungan satu dengan yang lainnya, misalnya sebab dan akibat. Penyampaian informasi yang terencana dengan baik disajikan dengan urutan yang cocok merupakan cirri utama kegiatan menjelaskan.Pemberian penjelasan merupakan aspek yang sangat penting dari kegiatan guru dalam interaksinya dengan siswa di dalam kelas. 
Keterampilan membimbing diskusi kelompok kecil adalah salah satu cara yang dapat dilakukan untuk memfasilitasi sistem pembelajaran yang dibutuhkan oleh siswa secara kelompok. Untuk itu, keterampilan guru harus dilatih dan dikembangkan, sehingga para guru memiliki kemampuan untuk melayani siswa dalam melakukan kegiatan pembelajaran kelompok kecil.

Pengelolaan kelas adalah keterampilan guru untuk menciptakan dan memelihara kondisi belajar yang optimal dan mengembalikannya bila terjadi gangguan dalam proses pembelajaran, seperti penghentian perilaku siswa yang memindahkan perhatian kelas, memberikan ganjaran bagi siswa yang tepat waktu dalam menyelesaikan tugas atau penetapan norma kelompok yang produktif.

Pembelajaran individual merupakan pembelajaran yang paling humanis untuk memenuhi kebutuhan dan inters siswa, walaupun untuk kondisi pendidikan di Indonesia, hal ini sangat jarang dilakukan. Namun, pada hakikatnya guru dapat melakukannya biarpun pembelajaran dilakukan secara klasikal, tetapi sentuhan tetap individual.

Menutup pelajaran merupakan kegiatan yang dilakukan oleh guru untuk mengakhiri kegiatan pembelajaran. Kegiatan ini dimaksudkan untuk memberikan gambaran menyeluruh tentang apa yang telah dipelajari oleh siswa, mengetahui tingkan pencapaian siswa dan tingkat keberhasilan guru dalam proses pembelajaran. Komponen menutup pelajaran adalah meninjau kembali penugasan materi pokok dengan merangkum atau menyimpulkan hasil pembelajaran dan melakukan evaluasi antara lain dengan cara mendemonstrasikan keterampilan, mengaplikasikan ide baru pada situasi lain, mengeksplorasi pendapat siswa sendiri dan memberikan soal-soal tertulis.

Oleh karena itu, simulasi sangat relevan digunakan sebagai metode mengajar dengan asumsi tidak semua proses pembelajaran dapat dilakukan secara langsung pada objek yang sebenarnya sesuai dengan pendapat Yamin (2009:149). Gladi resik merupakan salah satu contoh simulasi, yakni memperagakan proses terjadinya suatu upacara tertentu sebagai latihan untuk upacara sebenarnya supaya tidak gagal dalam waktunya nanti. Demikian juga untuk mengembangkan pemahaman dan penghayatan terhadap suatu peristiwa, penggunaan simulasi akan sangat bermanfaat. Metode simulasi bertujuan untuk: (1) melatih keterampilan tertentu baik bersifat profesional maupun bagi kehidupan sehari-hari, (2) memperoleh pemahaman tentang suatu konsep atau prinsip, (3) melatih memecahkan masalah, (4) meningkatkan keaktifan belajar, (5) memberikan motivasi belajar kepada siswa, (6) melatih siswa untuk mengadakan kerjasama dalam situasi kelompok, (7) menumbuhkan daya kreatif siswa, dan (8) melatih siswa untuk mengembangkan sikap toleransi. Dengan demikian, dipandang wajar jika penerapan simulasi peer teaching dengan teknik Nyaya Darsana mampu mengoptimalkan keterampilan mahasiswa dalam mengelola kelas atau meningkatkan keterampilan dasar mengajar.

\section{KESIMPULAN}

Berdasarkan uraian pembahasan di atas dapat disimpulkan bahwa penerapan simulasi peer teaching dengan teknik Nyaya Darsana dapat meningkatkan keterampilan dasar mengajar pada mahasiswa semester VI Program Studi Pendidikan Agama Hindu STKIP Agama Hindu Amlapura tahun akademik 2016/2017 dari persentase keberhasilan pada siklus I sebesar $87,10 \%$ menjadi $93,55 \%$ pada siklus II.

\section{DAFTAR PUSTAKA}

Anggreni, N. M. (2016). KONSTRUKSI BUDAYA MUTU RELEVANSINYA DENGAN MANAJEMEN MUTU GURU DALAM PEMBELAJARAN PENDIDIKAN AGAMA HINDU. Jurnal Penjaminan Mutu, 2(2), 84-92.

Juliantari, N. K. (2011). Modul Strategi Pembelajaran. Amlapura: STKIP Agama Hindu. 
Juliantari, N. K. (2013). Modul Teori dan Praktik Keguruan. Amlapura: STKIP Agama Hindu.

Kerti, N. N. (2018). Penerapan Catur Pramana Sebagai Metode Ilmiah Dalam Peningkatan Mutu Pembelajaran Agama Hindu. Jurnal Penjaminan Mutu, 4(1), 87-94.

Suardeyasa, I G. N. (2010). Penggunaan Teknik Nyaya Darsana dalam Meningkatkan Pemahaman Siswa terhadap Ajaran Widi Tattwa pada Mata Pelajaran Pendidikan Agama Hindu di Kelas IV SD Negeri 6 Tianyar Barat Tahun Ajaran 2009/2010. Laporan Penelitian (tidak diterbitkan). Dinas Pendidikan Pemuda dan Olahraga Kabupaten Karangasem.

Sudijono, (2006). Statistik Pendidikan . Jakarta: PT Raja Grafindo Persada. Suratmini, dkk. (2002). Agama Hindu. Jakarta: Ganeca Exact.

Tim Penyusun. (2003). Undang-undang RI Nomor 20 Tahun 2003 tentang Standar Nasional Pendidikan. Jakarta: Depdiknas.

Yamin, M. (2009). Profesionalisme Guru dan Implementasi KTSP. Jakarta: Gaung Persada Press. 